\title{
DIE GEBED: ENKELE GESIGSPUNTE IN VER- BAND MET DIE AARD EN DIE INHOUD VAN DIE CHRISTELIKE GEBED MET BESONDERE VERWYSING NA DIE HEIDELBERGSE KATE- GISMUS
}

\author{
C J WETHMAR
}

\begin{abstract}
Prayer: Some aspects of the nature and content of Christian prayer with special reference to the Heidelberg Catechism

This article briefly describes a few basic aspects of the Reformed doctrine on prayer as represented by the Heidelberg Catechism. The focal point of this view is the conviction that prayer is primarily rooted in God's providential acts towards man and only secondarily in man's dialogical relationship to God. The concrete applicability of this basic tenet is then studied by way of a short analysis of the manner in which the Heidelberg Catechism explains the Lord's Prayer. The approach suggested by this Catechism seems to be able to provide solutions to some present day problems experienced with prayer - problems represented by terms such as "lethargy", "resistance" and "distrust".
\end{abstract}

\section{Inleiding}

Gebed is een van die mees basiese uitinge van die Christelike godsdiens. In 'n Christelike huis word dit van kindsbeen af aangeleer met die gevolg dat vele Christene meen dat hulle presies weet wat gebed is. Tog gebeur dit telkens weer dat hierdie sekere wete deur onsekerheid oorweldig word. En wanneer so ' $n$ ervaring dan tot nadere besinning oor die gebed dring dan blyk dat die gebed allermins ' $n$ eenvoudige saak is. Dit is nie net maar kundigheid wat ' $n$ mens op 'n gegewe oomblik eens en vir altyd bemeester nie. Die gebed blyk niks minder te wees nie as ' $n$ geheimenis waarteenoor elke gelowige hom steeds weer in die posisie bevind van die aanvanklike dissipels wat moes vra: "Here leer ons bid".

Juis omdat die gebed ' $n$ geheimenis is, kan dit nie die bedoeling van hierdie bydrae wees om al die verskillende gebedsprobleme wat Christene telkens weer ervaar, te probeer oplos nie. Gebedsprobleme kan nie eenvoudig net met die aanduiding van 'n paar kunsgrepe of tegnieke opgelos word nie. "Wel egter is dit die bedoeling van hierdie artikel om enkele gesigspunte in verband met die aard en die inhoud van die ware Christelike gebed aan die orde te stel sodat oorweging daarvan 
miskien kan help om met konkrete gebedsprobleme oor die weg te kom.

Dit sal verder nie eers moontlik wees om slegs maar 'n ontleding van al die voorkomende gebedsprobleme te gee nie. Dit kan egter verhelderend wees om in die verbygaan net te verwys na enkele dikwels voorkomende gebedsmoeilikhede om later kortliks te let op die implikasies wat 'n Bybels verantwoorde gebedsbeskouing daarop kon hê. 'n Studie van die resente literatuur in verband met die gebedsproblematiek ${ }^{2)}$ toon aan dat die volgende drie tipes gebedsprobleme dikwels voorkom:

(a) Gebedsvermoeidheid en biddeloosheid. Waar die gebedslewe nie deur ' $n$ egte geestelike gemotiveerdheid gedra word nie, word dit gou ervaar as 'n gewoonte wat nie pas in die haastige styl van die moderne lewe nie. Die gevolg is dat gebedsvermoeidheid intree wat spoedig tot algemene biddeloosheid lei.

(b) Gebedskuheid. Die sekularistiese mens ontwikkel die gedagte dat die gebed nòg by die mens nòg by God pas. Die moderne outonome mens vind dit onaanvaarbaar dat hy deur die gebed blyke van totale afhanklikheid moet gee. En in ooreenstemming met en in aansluiting by hierdie mens- en wêreldbeeld ontstaan ' $n$ Godsbeskouing waarvolgens dit vir God onwaardig sou wees om telkens maar weer afhanklik te wees van die gebede van sy onderdane.

(c) Gebedswantroue. Hierdie derde tipe gebedsprobleem hou nie soseer verband met lewensbeskoulike vrae nie, maar eerder met die vraagstuk van dit wat as die onverhoorde gebed ervaar word. Daar is diegene wat, indien hulle gebede nie direk die deur hulle gewenste resultate oplewer nie, kom tot gebedswantroue en voorsienigheidsongeloof.

Nou is dit so dat baie gebedsprobleme, en met name ook van dié wat tuishoort onder die kategorieeë wat pas genoem is, saamhang met die feit dat die gebed as 'n enkelvoudige en opsigselfstaande aktiwiteit gesien word. Maar so ' $n$ aktiwiteit is die gebed nie. En die vermelde gebedsprobleme sal 'n mens alleen dan op 'n verantwoorde wyse kan benader indien grondige oorweging geskenk word aan die geloofs- en teologiese verbande waarbinne die gebed funksioneer. Wie met hierdie verbande vanuit Gereformeerde oriëntasie op die spoor wil kom, kan veel baat vind by ' $n$ bestudering van die Heidelbergse Kategismus se leer oor die gebed. Dit is die geval omdat die Kategismus nie alleen in sy laaste 
veertien vrae en antwoorde die gebed as ' $n$ afsonderlike tema behandel nie, maar omdat die gebed ook nog op 'n verdere tweevoudige wyse met die Kategismus as geheel as't ware vervleg is. In die eerste instansie vloei die grondoortuigings van die Kategismus, wat tot uitdrukking kom in die benaminge van die drie hoofdele daarvan, oor in die leer aangaande die gebed wat in die vermelde slotgedeelte aan die orde kom. ${ }^{3 \prime}$

Deur hierdie wyse van samestelling gee die Kategismus te kenne dat hy die gebed nie as ' $n$ toevallige en geïsoleerde daad in die menslike lewe sien nie, maar eerder as 'n wyse waarop die geloof bewustelik verwerklik word. Maar in die tweede instansie is dit ook so dat veel van die leerstellige materiaal in die Kategismus in 'n gebedsgesindheid geformuleer is. Hieruit blyk dat die opstellers van die Kategismus besef het dat 'n belydenis ' $n$ uitdrukkingswyse is wat, naas getuienis teenoor die medemens, altyd terselfdertyd ook spreke tot God is. Dit is daarom ook begryplik dat die Heidelbergse Kategismus in die Gereformeerde tradisie steeds ook weer as 'n gebede- en troosboek gefunksioneer het. En dit kon gebeur het omdat die hele Kategismus ervaar is as 'n uitgebreide antwoord op die heel eerste vraag waarmee hierdie belydenisskrif begin, die ingrypende vraag naamlik: "Wat is jou enigste troos in lewe en in sterwe?"'4)

In die volgende paragrawe sal eerstens gepoog word om die teologiese verbande en uitgangspunte waarin die Heidelbergse Kategismus die gebed plaas, aan te dui om daarna aandag te skenk aan die wyse waarop hierdie uitgangspunte konkreet aan die orde kom in die Kategismus se behandeling van die "Onse Vader".

\section{Uitgangspunte}

\subsection{Die reformatoriese aksent}

Voordat die Heidelberger die modelgebed van die Here behandel, word eers twee algemene vrae in verband met die gebed bespreek. Dit is opvallend dat die Kategismus hierdie algemene bespreking nie begin met ' $n$ noukeurige definisie van wat gebed is of met ' $n$ versigtige aanduiding van die delikate en ingewikkelde aard van hierdie tema nie. Inteendeel, met ' $n$ verrassende direktheid word die kernvrae waarom dit gaan sonder meer gestel:

Waarom is die gebed vir Christene nodig (vraag 116)? Hoe moet 'n gebed wees wat goed is voor God en wat deur Hom verhoor word Ivraag 117)? Wat het God ons beveel om te bid (vraag 118)?

Uit die antwoorde op hierdie vrae word die tipies Reformatoriese en Bybelse aksent van die Kategismus se leer oor die gebed duidelik. Hierdie 
aksent bestaan in hoofsaak daarin dat die gebed nie in die eerste instansie ' $n$ werksaamheid is wat uit die lewe en lewensbehoeftes van die mens self opkom nie, maar dat die gebed sy oorsprong het in die drieënige God wat as Skepper, Versoener en Verlosser die mens aanspreek en hom in hierdie wêreld plaas op 'n heilsweg wat gerig is op die koms van die volkomenheid van die Godsryk waar God alles in almal sal wees. ${ }^{5)}$ Die gebed word hier dus gesien as ' $n$ daad van dankbaarheid wat voortvloei uit die ervaring van verlossing uit verlorenheid.

In hierdie opvatting oor die gebed wat in die laaste deel van die Heidelberger na vore tree, word dit wat die Kategismus in sy eerste twee hoofdele uitspreek, opgeneem en geaktualiseer. In die gebed bely 'n mens naamlik hoe groot sy sonde en ellende is. En al het hyself geen verdienste nie, beroep hy hom op die verlossing wat Christus verwerf het. Die mens doen dit alles omdat God deur Sy Woord en Gees aan die mens deel wil gee aan die voleinding van God se heilsdoel met die wêreld. Dit beteken dat die gebed ' $n$ genademiddel is waardeur die Heilige Gees die heil wat Christus verwerf het in die lewe van die gelowige wil toepas. Of anders gesê: volgens die Kategismus word die gebed alleen in sy volle diepte begryp indien dit gesien word in die verbande van heiliging, regverdiging en voorsienigheid. ${ }^{6)}$

\subsection{God as Vader en die mens as kind}

Die gesigspunt wat so pas gestel is, is in die Reformasietyd beklemtoon deur die groot betekenis wat geheg is aan die term "vader" om God mee aan te dui. 'n Mens sou, byvoorbeeld, Calvyn se hele teologie van die gebed kon opvat as 'n uitleg van wat die woord "vader" in sy toepassing op God beteken." Dieselfde verskynsel tree na vore in die veelheid van uitlegginge van die modelgebed van die Here wat in die Reformasietyd tot stand gekom het. Hierdie beklemtoning van die vaderskap van God hang saam met die nuwe ontdekking wat in die Reformasie gedoen is van wat geloof en regverdiging en heiliging beteken. Daar is naamlik opnuut ontdek dat die verhouding tussen God en mens deur die Woord van God voorgestel en bepaal word." Gevolglik is hierdie verhouding gesien as ' $n$ gespreksverhouding en dus as iets intens persoonlik van aard en nie as iets hoofsaaklik institusioneels soos die geval was in die voorreformatoriese teologie nie. Hiermee gaan gepaard nie alleen 'n herontdekking van 'n vrye lees van die Bybel nie, maar ook van 'n vrye en spontane persoonlike gebedslewe. Nou kan daar weer gebid word en nie net gebede opgesê word nie. Daarom kan Antwoord 120 van die Heidelbergse Kategismus met sigbare opgewondenheid sê: God het immers deur Christus ons Vader geword, en Hy sal ons dit wat ons van Hom met 
'n ware geloof vra, baie minder weier as wat ons vaders ons aardse dinge ontsê. Aangesien ons om Christus ontwil, uit genade tot kinders van God aangeneem is, mag en moet ons God in die gebed as "Vader" aanspreek. Trouens, elke gebed is as sodanig 'n getuienis van die vaderskap van God. En alhoewel ons nie verdien dat ons gebede verhoor word nie, wil God dit ter wille van Christus tog doen. ${ }^{9}$ 'Wanneer ons gebede verhoor word - en dit geld sowel die gebede om liggaamlike as geestelike dinge - dan geskied dit in die perspektief van die vergewing van ons sonde.

\subsection{Gebed in die Naam van Jesus Christus}

Uit wat oor die Vaderskap van God en die kindskap van die mens gesê is, is dit duidelik dat die frase "in die Naam van Jesus Christus" nie maar net 'n plegtige dog verder betekenislose slotfrase van die gebed is nie. Om in die Naam van Jesus te bid, impliseer nie 'n magiese gebruik van sy Naam nie, maar dit beteken dat die bidder hom invoeg in die breë plan wat God in Christus met hierdie wêreld het. Dit beteken dat dit ten diepste in die Christelike gebed moet gaan om dit wat Christus na aan die hart lê. Van so 'n gebed geld die woord van Jesus: "Wat julle ook al in my Naam vra, sal ek doen, sodat die Vader deur die Seun verheerlik kan word". ${ }^{10)}$

'n Belangrike verdere gesigspunt in verband met die gebed in die Naam van Jesus is dat ons ons daarmee nie alleen bevind in die ruimte van die werk wat Jesus op aarde gedoen het nie. Maar langs hierdie weg word ons gebed ook in verband gebring met die voorspraak wat die opgestane Christus, die regverdige, vir ons by die Vader doen. ${ }^{11}$ ) In die Naam van die Middelaar vind ons gebed sy begronding en regverdiging.

\subsection{Gebed as dialoog}

In die lig van wat tot sover gesê is, sal dit duidelik wees dat die gebed wel 'n gesprek tussen die mens en God is, maar dan 'n gesprek van onvermoede dimensies. Dit is nie ' $n$ gesprek wat eensydig in die mens sy oorsprong het en van die mens na God verloop nie. Die gebed is ten diepste nie ' $n$ beweging na God toe nie, maar 'n beweging van God vandaan. Die gebed verloop dus ook nie bloot in die skema van 'n ek-uverhouding nie, maar wel op so ' $n$ wyse dat God self ook steeds by die gebedsgebeure betrokke is. ${ }^{12)}$ Miskien hang veel gebedsprobleme daarmee saam dat die Samuel-gesindheid van "Praat, Here, u dienaar luister!", vervang word met 'n oneerbiedige, maar dan ook 'n vrugtelose "Luister, Here, u dienaar praat!". 13) Die egte Christelike gebed word in 'n 
houding van hoor gebore. Die mens wat in die gebed na God soek, stel vas dat hy soek omdat hy reeds deur God gevind is. Die gebed self is die uitdrukking van Gods genade en dit verloop in die ruimte van Gods genade.

\subsection{Gebedsverhoring}

Waar die gebed in die pas beskrewe verbande gesien word, kom die probleem van die gebedsverhoring in 'n heel nuwe lig te staan. In 'n sekere sin is die regte gebed reeds ' $n$ stuk gebedsverhoring op sigself. Die bidder hoef hom nie in te span om by God uit te kom nie. Hy hoef ook nie sy eie heiligheid saam te bring na God toe nie. Die gebed staan nie aan die einde van die weg van heiligmaking nie, maar aan die begin daarvan. Daar hoef nie ' $n$ al te groot klarigheid vir die gebed gemaak te word nie. Die gebed staan in die klaarheid van Gods genade. Die heiliging voltrek homself in die gebed as toe-eiening van en ' $n$ lewe in die regverdiging. Die gebed weerspieël 'n lewe op die toonhoogte van die Gees.

Waar die gebed in God self en in sy raadsplan vir hierdie wêreld begrond is, is die verhoring van die gebed ook in Hom begrond. So word Sy wil die maatstaf vir dit wat as geregverdigde verwagtinge in verband met gebedsverhoring mag geld.

\subsection{Gebed as gebod}

Die grondmotief wat aan die Kategismus se leer oor die gebed ten grondslag lê, naamlik dat God nie alleen maar die adres van ons gebede is nie, maar dat Hy self by daardie gebede betrokke is, tree op 'n opvallende wyse na vore in die feit dat die gebed as 'n gebod bedryf word. In die eerste Sondagsafdeling van die Kategismus wat oor die gebed handel en waar kortliks die waarom, hoe en wat van die gebed aan die orde kom, word in elkeen van hierdie gevalle, drie maal dus, daarvan gewag gemaak dat die gebed ' $n$ bevel en ' $n$ eis van God is. Maar hierdie eis geld hier nie as ' $n$ direkte wet nie, maar as ' $n$ in-Christus-vervulde-wet en daarom as wyse waarop die Heilige Gees ons lewens wil heilig. Die derde hoofdeel van die Kategismus word in sy geheel gewy aan die dankbaarheid wat ons aan God vir die verlossing skuldig is. Hierdie dankbaarheid kom tot uitdrukking in twee dele, te wete gebod en gebed. Van hierdie twee dele is die gebed die vernaamste omdat regverdiging en heiliging daarin aktueel en bewustelik verbind word. In die lig van die opbou van die Kategismus sou ' $n$ mens kon sê in die gebed word al drie hoofdele van die Heidelberger voltrek. In die gebed word op die vlak van die dankbaarheid die kennis van die sonde en die ontvangs van die verlossing 
herhaal. ${ }^{14)}$ In die gebed kom die ritme van die geestelike lewe tot uitdrukking. Daarom is die gebed nie 'n eenmalige daad nie, maar moet dit sonder ophou geskied. ${ }^{15}$,

Waar gebed gebod is en ten diepste dus nie opkom uit die spreke van die mens nie, maar uit die hoor van Gods Woord, sal dit duidelik wees dat volhardende biddeloosheid nie maar net 'n menslike swakheid is nie maar weerstand teen die Gees van God. Biddeloosheid is sonde.

\subsection{Die geheimenis van die gebed}

In die lig van die uitgangspunte wat tot sover geformuleer is, kan nou gekonkludeer word dat die gebed inderdaad 'n geheimenis is - nie alleen 'n Christologiese en 'n Pneumatologiese geheimenis nie, maar ten diepste 'n Trinitariese geheimenis. Wat hiermee gesê is, kan by wyse van samevatting kortliks beklemtoon word in die volgende opmerkinge, wat oor die aanvanklik vermelde gebedsprobleme gemaak word:

(a) Biddeloosheid is nie 'n toestand wat as iets relatief onskuldigs en as slegs maar ' $n$ uiting van menslike swakheid aanvaar kan word nie. Wie hom werklik oopstel vir Gods Woord en Gees hoef nie homself oor sy biddeloosheid heen te tel nie, maar word opgeneem in die beweging waarmee Gods Gees met sy volk in hierdie wêreld op weg is.

(b) Gebedskuheid. Oor wat wesenlik tot die bestaan van God enersyds en tot die bestaan van die mens andersyds behoort, hoedanig die verhouding tussen God en mens is en wat die wêreldbeskoulike implikasies hiervan vir die gebed is, kan nie as abstrakte probleem begryplik gemaak word nie, maar slegs vanuit die brug wat deur die Middelaar geslaan is. Daarom dat gestel moet word dat ons gebed sy begronding en regverdiging alleen in die Naam van die Middelaar vind.

(c) Gebedswantroue. Die Kategismus beskryf die voorsienigheid van God vanuit die vergifnis van ons sonde en dus vanuit die verlossing wat Christus gebring het. ${ }^{16)}$ Wat as gebedsverhoring verwag mag word en inderdaad deur die toegewyde gelowige verwag word, word bepaal deur die verbondenheid aan Christus en deur die breë verbande van die koninkryk van God.

\section{Konkretisering}

Met die uitgangspunte wat pas geformuleer is in gedagte, word ver- 
volgens aandag geskenk aan die inhoud van die modelgebed van die Here.

\subsection{Die Aanhef}

Na die tema van die vaderskap van God wat in die aanhef van die Onse Vader ter sprake kom, is reeds hierbo verwys. ${ }^{17}$ ) By dit wat reeds gesê is, moet nog 'n motief wat in die uitdrukking "Onse Vader wat in die hemel is" aanwesig is, vermeld word. Dit is die gedagte van die gelyktydige transendensie en immanensie van God. ${ }^{18)}$ Die verhewe hemelse God (transendensie) is tegelykertyd die God wat ons Vader is en met ons bemoeienis maak. In Christus het die almagtige God naby ons gekom. God self het so die oneindige kloof tussen God en mens oorbrug. So het Hy die weg vir die gebed geopen.

\subsection{Die eerste bede: "Laat U Naam geheilig word"}

Die Kategismus interpreteer hierdie bede as 'n bede om kennis en erkenning. ${ }^{19)}$ Dit is dus die bede dat die Naam van God só in ons lewe sal werk, dat ons tot ware kennis van God sal kom en dat hierdie kennis in ons lewe daartoe sal lei dat andere God ook waarlik sal leer ken. Uit hierdie eerste bede blyk dat die diepste behoefte van ons lewe anders lyk as wat ons normaalweg vermoed. Ons diepste behoefte hou nie verband met ons daaglikse brood of selfs met ons skuld nie. Ons diepste behoefte is aan die Naam van God in ons lewe. Eers wanneer 'n mens God ken, leer jy jouself waarlik ken en kom jy werklik by jouself uit.

Dat ons om hierdie regte kennis wat die Naam van God ons bied dringend en in die eerste instansie moet bid, beteken dat ons dit nie het nie. En dat ons dit nie het nie, is nie bloot ' $n$ kwessie van die afwesigheid van kennis nie. Dit is eweseer ' $n$ kwessie van die aanwesigheid van verkeerde kennis. 'n Mens kan naamlik met die Naam van die Here só omgaan dat dit tot onware kennis van God lei. ${ }^{20}$ ) Dit is juis dít wat in die derde gebod verbied word met die formulering: "Jy mag die Naam van die Here jou God nie misbruik nie". 'n Nadere ondersoek van die betekenis van hierdie verbod toon aan dat daar 'n tweevoudige misbruik van Gods Naam is wat afgewys word, enersyds om Gods Naam te ignoreer omdat gemeen word dat dit nie werklik van gewig en betekenis is nie, en andersyds aanwending van Gods Naam vir doeleindes wat nie met Gods wil te versoen is nie. ${ }^{21}$ ' Wie die Naam van God só misbruik, staan onder die oordeel van God. In die heiliging van die Naam van God gaan dit om die presiese teendeel van die misbruik daarvan.

Om die volle diepte en erns van die eerste gebod in verband met die 
Naam en die derde gebod daaroor reg te begryp, moet in gedagte gehou word dat ' $n$ naam in Bybelse tye nie net ' $n$ toevallige etiket was soos vandag meestal die geval is nie. Tussen ' $n$ naam en die wese van ' $n$ persoon is die nouste verband gesien. ${ }^{22}$ ) Wanneer daar nou in die vermelde gebed en gebod na die Naam van God verwys word, word daarmee bedoel dat die Naam van God op ' $n$ besonder intense manier na God verwys. Die Naam van God is in feite God self soos Hy Hom aan ons bekendmaak. ${ }^{23}$ ) Vandaar dat die Kategismus sê dat om Gods Naam te heilig vir die mens beteken om God reg te ken. ${ }^{24)}$ Om Gods Naam reg te ken, beteken om met God in ' $n$ heel bepaalde verhouding te leef en met name in ' $n$ sodanige verhouding dat die Godheid van God in daardie verhouding volledig tot sy reg kom.

Gods Naam word geheilig daar waar God Homself werklik as God betoon en waar hierdie heiligheid geken word. Dit is dus nie die mens wat in die eerste instansie subjek van hierdie gebeure van heiliging is nie. Dit is God self wat sy eie Naam heilig en die gelowige word geroep om daarby betrokke te wees deurdat hy die heiligheid van God erken.

Uit die lewe en sterwe van Jesus Christus het duidelik geword dat God Homself nie heilig ten koste van mense nie, maar tot die heil van die mens. Gods heerlikheid kom juis tot uitdrukking in die redding van mense. Van die kant van die gelowige bestaan die heiliging en verheerliking van Gods Naam in die lof op grond van die verlossing wat hy ervaar het en ook nog verwag.

Die Kategismus lê klem daarop dat die erkenning van Gods Naam nie net ' $n$ intellektuele aangeleentheid is nie, maar 'n alsydige geloofsgebeure. Die Kategismus beklemtoon in hierdie verband dat die hele lewe van die gelowige in diens moet staan van die heerlikheid en eer van God. Hiermee moet die verskriklike moontlikheid afgeweer word dat Gods Naam gelaster kan word vanweë die optrede van hulle wat bely dat hulle in God glo. 25 )

\subsection{Die tweede bede: "Laat u koninkryk kom"}

Hierdie tweede bede staan in noue verband met die eerste. Die invoeging van die mens in die geskiedenis van God met hierdie wêreld word hier tot uitdrukking gebring. Waar die eerste bede nog meer vanuit die sfeer van 'n persoonlike verhouding kom, gaan dit in die tweede bede meer om die institusionele. In die tweede bede gaan dit nie net om God as Vader nie, maar ook om God as Koning.

Die voorstelling van die koninkryk kan beskou word as een van die mees sentrale kategorieë wat die Bybel gebruik om die verhouding tussen God en Sy skepping mee aan te dui. Die volgende omskrywing 
sou van hierdie voorstelling gegee kon word: Die koninkryk van God is die koningsheerskappy van God wat in Christus sy volmaakte gestalte gevind het, ${ }^{26)}$ vanuit Christus om volledige erkenning op aarde roep ${ }^{27}$, en vanuit Christus sy glorieryke volheid tegemoetgaan. Dis ' $n$ volheid wat 'n nuwe mensheid en 'n nuwe hemel en 'n nuwe aarde omvat. ${ }^{28}$ ) Diegene wat die Koning se roepstem gehoor en positief daarop geantwoord het, vorm 'n volk van God in diens van die koninkryk. Hulle is burgers van die koninkryk wat leef vir die koms van die koninkryk. Hulle begeer dat die koninkryk in hulle eie lewens en in die lewens van mense uit alle nasies gestaltes sal vind, op alle plekke en op alle lewensterreine. Hulle hunker na die koms van die koninkryk. ${ }^{29}$ )

Dit is hierdie koninkryk waarom die gelowige in hierdie bede opgeroep word om te bid. In 'n sekere sin kan hierdie bede beskou word as die kern van die hele Onse Vader. Die res van hierdie gebed ontvou vanuit hierdie kern. Elkeen van die ander bedes is in feite ' $n$ gebed om 'n bepaalde faset van die koninkryk. ${ }^{30}$ ) Waar Gods Naam geheilig word en sy wil gedoen word, daar kom die koninkryk. Waar om brood gebid word en daarvoor gedank word, waar skuld vergewe word en mense van die Bose verlos word, daar kom die koninkryk. ${ }^{311}$

Die Kategismus se uitleg van die gebed om die koms van die koninkryk bevat ook nog die volgende elemente wat hier net kortliks aangestip kan word:

(a) Die bede om die koninkryk begin by die bidder. Die koninkryk het reeds gekom. Dit is in feite sedert die skepping reeds die geval en sedert die koms van Christus geld dit nog des te meer. Maar die gelding van die koninkryk is nie iets vanselfsprekend nie. Ten diepste word dit deur die Woord van God tot stand gebring en in die geloof verwerklik. En die geloof is ' $n$ lewenswerklikheid wat telkens weer op die ongeloof verower moet word. Daarom impliseer die bede om die koms van die koninkryk dat die gelowige steeds weer bid om 'n toename in gehoorsaamheid en toewyding. In verband hiermee begin die gebed om die koninkryk nie met ' $n$ verwysing na ander nie, maar na die gelowige self.

(b) Kerk en koninkryk. Waar die koninkryk ten diepste in die geloof verwerklik word, staan die kerk as geloofsgemeenskap in 'n besondere mate in diens van die koninkryk. En daarom moet om die bewaring en vermeerdering van die kerk gebid word, sodat hy 'n suiwere diens aan die koninkryk kan lewer. ${ }^{32)}$

(c) Ryk en anti-ryk. Dat die geloof steeds as geloofstryd bestaan, im- 
pliseer dat die gebed ook steeds ' $n$ gebedstryd is. Hierdie stryd is gerig teen die werke van die Bose. Hierdie gesigspunt kom in die sesde bede eksplisiet weer na vore.

(d) Gebed en voleinding. As strydgebeure is die gebed gerig op 'n bepaalde doel. Die egte Christelike gebed kon nie maar net vervlak tot 'n oppervlakkige pligpleging nie, want dit staan in die spanning van die geloofslewe tussen die alreeds van die koninkryk enersyds en die volkomenheid van die volheid waarheen die kerk op weg is, andersyds.

\subsection{Die derde bede: "Laat u wil geskied, soos in die hemel net so ook op die aarde"}

Die derde bede sluit op sy beurt nou by die tweede aan. Dit stel ' $n$ essensiële faset daarvan aan die orde. Die koninkryk van God kan alleen kom waar sy wil geskied. En dat die wil van God in ons lewens geskied, is geen vanselfsprekendheid nie. Vanuit die menslike natuur gesien, is die teendeel selfs waar. Vanuit ons natuur gesien, geskied die wil van God nie in ons lewe nie. Daarom moet ons bid dat dit gebeur.

Hierdie gebed geskied dus in die bewussyn van die raaiselagtige werklikheid van die sonde. Dit is 'n gebed uit die diepte, uit die onmag van ons verlorenheid. Hierdie bewussyn is deur die apostel Paulus akkuraat beskryf toe hy gesê het: "Ek weet immers dat die goeie nie in my woon nie, nie in my sondige aard nie. Daar is by my wel die wil om die goeie te doen, maar ek doen dit nie. Die goeie wat ek wil doen, doen ek nie, maar die slegte wat ek nie wil doen nie, dit doen ek ... So vind ek dan hierdie wet in my: ek wil die goeie doen, maar al wat ek doen is die slegte." ${ }^{33)}$ Die gebondenheid en gebrokenheid van die wil van die mens bestaan nie daarin dat hy deur omstandighede van ' $n$ eie wil beroof word nie, maar daarin dat hy in vryheid die slegte wil.

In hierdie derde bede is die mens in feite besig om teen homself in te bid. Hy vra dat die Here sal gee dat hy sy eie kwade wil sal prysgee ten einde hom met Gods wil te vereenselwig. En so 'n prysgee geskied nie maklik nie. Dit gaan met verbryseling en verslaenheid gepaard. Om hierdie verbryseling en verslaenheid word in hierdie bede gebid. Dit is dus nie 'n woord wat in halwe gelatenheid gespreek word nie. Dit is ' $n$ worstelende woord: "Gee dat ons ons eie wil prysgee om aan $u$ wil, wat alleen goed is, sonder verset gehoorsaam te wees", interpreteer die Kategismus. ${ }^{34)}$ Hierdie gawe word ' $n$ mens alleen deelagtig in gemeenskap met Hom wie se spyse dit was om die wil van sy Vader te doen.

Opvallend van die Kategismus se uitleg van hierdie gebede is dat 
dit nie net ten opsigte van die gelowiges geldend gemaak word nie, maar ten opsigte van alle mense. Weliswaar begin dit met die eie skuld en die bewussyn dat die ganse menslike geslag in hierdie gebrokenheid betrokke is, maar juis daarom blyk hierdie interpretasie ' $n$ besonder ruim visie te bied: die begeerte dat alle mense aan Gods wil onderworpe sal wees. Wanneer dit gebeur sal dit letterlik hemel op aarde wees. Alle mense sal dan nuut wees en ook alle dinge. Hierdie gebed geld ten diepste dus nie slegs alle mense nie, maar ook die hele aarde. Dit vra om die voleinding van die skepping. Net soos met die tweede bede die geval was, het ook die derde bede 'n eskatologiese visie, ' $n$ visie op die voleinding waar "God alles sal wees vir alles." 35 ,

Maar al is hierdie bede ingevoeg in 'n eskatologiese visie leer die Kategismus dat hierdie bede ook ' $n$ heel konkrete gebed is. Dit gaan nie net om die wil van God oor die algemeen nie, maar ook heel konkreet om die eise wat die wil van God vir die gelowige inhou in sy amp en beroep. ${ }^{36)}$

\subsection{Die vierde bede: "Gee ons vandag ons daaglikse brood"}

Hoeseer die biddende mens ook al op God ingestel is en hoeseer dit hom ook om geestelike dinge gaan, hy is en bly ' $n$ liggaamlik-stoflike mens. Die mens kan nie anders nie. Hy mag ook nie anders nie. Want God het hom so gewil en so gemaak. As liggaamlik-stoflike mens mag en moet hy voor God intree in die gebed. Hierdie liggaamlikheid moet hy selfs voor God ter sprake bring. Daaroor gaan dit juis in sy gebed om die daaglikse brood.

Die bedoeling is nie dat die term "brood" net na hierdie een voedselsoort verwys nie. Volgens die uitleg van die Kategismus word met hierdie term aangedui alles wat ons vir ons liggaamlike bestaan benodig. Nou sou 'n lang diskussie gevoer kon word oor wat 'n mens werklik vir jou liggaamlike bestaan nodig het. En seer seker sou 'n saak daarvoor uitgemaak kon word dat die armoede-ideaal nie noodwendig oor die algemeen tot ' $n$ Christelike lewenstyl behoort nie. Die Christen mag streef na 'n menswaardige bestaan en na 'n bepaalde sosiale en ekonomiese leefruimte waarin hy homself mag uitleef en verbly. Hierin mag die gelowige iets van Gods milddadigheid ervaar. ${ }^{37}$ )

Maar tog sal 'n mens nie jou oë mag sluit vir die feit nie dat die gebruik van die term "brood" as samevatting van die menslike behoeftes hier tog ook,'n sekere aksent van soberheid lê. Die mens leef van dit wat hy van God ontvang. Daarvan leef hy met die ander mense saam. Daarom word van ons brood gepraat. Wie dit alles in ag neem en wie so bid, sal nie anders kan as om tot ' $n$ verantwoorde eenvoud in sy 
lewenstyl te kom nie.

Die brood waarom dit hier gaan, is egter nie net iets waaraan ons uitsluitlik in ' $n$ insidentele noodtoestand behoefte het nie. Dit gaan om ons daaglikse brood. Hierin is ook die gedagte opgesluit dat dit gaan om dit waaraan die mens hom in die gereelde gang van sy lewe wy, te wete sy arbeid. ${ }^{38)}$ Dat die arbeid hier in die konteks van die gebed ter sprake kom, stel dit in ' $n$ heel bepaalde lig. Ook dit waarvoor ons werk, ontvang ons in feite uit die seënende hand van God. Verantwoorde arbeid behoort tot 'n Christelike lewenstyl. Maar die finale heil kom nie van werk af nie, dog alleen van God.

Die gebed om die daaglikse brood word op 'n opvallende wyse gekwalifiseer: "Gee ons vandag ons daaglikse brood". Wie weet dat sy lewensonderhoud uit die hand van God kom, het die moed om die lewe dag vir dag te leef. Hy hoef nie oormôre se brood vandag te hê nie. Hy weet dat Gods genade elke môre nuut is.

\subsection{Die vyfde bede: "Vergeef ons ons oortredinge soos ons ook dié vergewe wat teen ons oortree"}

Soos met sovele tradisionele gebedsuitdrukkinge die geval is, geld ook vir die gebed om die vergifnis van sonde dat dit maklik in 'n leë pligpleging ontaard. Indien dit sou gebeur sou dit totaal onvanpas wees omdat hierdie bede van heel besondere betekenis is. Dit hang ten nouste saam met die hele Onse Vader self en trouens ook met die eie aard van die gebed oor die algemeen. Die gebed om die vergifnis van sonde beweeg in die ruimte wat deur die vaderskap van God bepaal word. Wie die "Onse Vader" bid, het God as Vader aanvaar. Deur die gebed as genademiddel, wil die Heilige Gees die heil wat Christus verwerf het, in die lewe van die gelowige toepas. Dit alles word voltrek in die gebed om die vergewing van sonde.

Hierdie gebed is deel van die Christen se lewe. ${ }^{39 l}$ Waar die Kategismus hierdie aksent lê, word aangedui dat die gebed tot die weg van heiligmaking behoort. Al is die gelowige in Christus geregverdig en al het hy dus voor God die status van regverdige; en al het hy van die sonde weggedraai en na God toe gedraai, is hy nogtans daagliks besig om uit hierdie werklikhede te leef in die vorm van die stryd teen die sonde. Aan hierdie waarheid het Luther uitdrukking gegee met die stelling dat die Christenmens terselfdertyd geregverdigde én sondaar is. ${ }^{40)}$ Die Christelike geloof word daagliks voltrek as 'n stryd teen die ongeloof. En hierdie stryd voltrek homself onder andere waar dan tog op 'n essensiële wyse in die gereëlde en volhardende gebed tree en in hierdie geval met name dan in die gebed om die vergifnis van sonde vra. God wil sy genade 
en Heilige Gees aan die gelowige gee. Maar Hy wil dit aan hulle gee wat Hom uit die hart met smeekbedes sonder ophou daarom bid en daarvoor dank. ${ }^{41}$

Die gedagte dat hierdie gebed om vergifnis verband hou met en opkom uit die ervaring van Gods genade, vind opvallende uitdrukking in die wyse waarop die Kategismus die kwalifikasie wat by hierdie gebed gevoeg word, uitlê. Juis die verrassende werklikheid dat gelowige mense mekaar hulle oortredinge vergewe, is 'n aanduiding daarvan dat hulle hulle in die ruimte van die werking van Gods genade bevind. Die uitdrukking "soos ons ook dié vergewe wat teen ons oortree", word hier dus nie as voorwaarde beskou waaraan die gelowige moet voldoen om vir Gods vergifnis te kwalifiseer nie. ${ }^{42)}$ Hierdie uitdrukking dien dus eerder as basis vir vrymoedigheid om ten spyte van die ervaring en die wete van hoe groot my sonde en ellende is tog my toevlug te neem tot die troon van genade.

\subsection{Die sesde bede: "En laat ons nie in versoeking kom nie maar verlos ons van die Bose"}

Dit is merkwaardig dat in twee van die ses bedes van die Onse Vader met die sonde geworstel word. In die vyfde bede vlug die gelowige as geregverdigde sondaar met sy sonde na God toe. In die sesde bede word Gods hulp gevra vir 'n vlug weg van die sonde af. 'n Gebed wat só verloop sou dus beskou kan word as 'n gebeure van voortgesette bekering.

Die mens wat in die lig van Gods genade pas die volle diepte en erns van die sonde raakgesien en ervaar het, weet dat wanneer hy op homself aangewese is, hy nie opgewasse is teen die omvattende mag van die Bose nie. Hierdie omvattende mag word deur die Kategismus omskryf as die duiwel, die wêreld en ons sondige natuur. Die aanslag teen die geloof is so gedug dat geen gelowige dit kan bekostig om nie deur die gebed daarteen weerstand te bied nie. Hierdie gebed om verlossing is ' $n$ gebed om die Heilige Gees wat die gelowige tot weerstand teen die sonde in staat stel.

In hierdie laaste twee bedes blyk dit dat die gebed inderdaad ook stryd is. Daarom is dit ' $n$ realisering van die stryd teen die ongeloof wat die geloof na sy wese altyd is. Oorweldig deur Gods genade is die gebed die wyse waarop die wapenrusting van die Christen voortdurend weer hanteer moet word. ${ }^{43}$

\subsection{Die afsluiting}

God wil die mens langs die weg van die gebed genadig wees. Hy is nie 
alleen die oorsprong van die gebed nie, maar die gebed kom ook in Hom tot rus. Die lewe vanuit sy krag en heerskappy oor die magte van sonde en dood lei tot die vrede wat alle verstand te bowe gaan. Wanneer die gebed ingebed word in Gods besigwees met die mens, beteken dit dat God nie alleen die gebed nie, maar ook die gebedsverhoring begrond. Hierdie wete spreek uit die gebruik van die woord "amen" om die gebed mee te sluit.

\section{NOTAS}

1. Vgl. in hierdie verband R Guardini, Vorschule des Betens, Einsiedeln-Zürich-Köln 1964. Kyk ook K Rahner, Von der Not und dem Segen des Gebetes, Innsbruck. 1949.

2. Uit die groot veelheid literatuur wat oor die gebed verskyn, kan hier na die volgende verwys word: H M Barth, Wohin - Woher mein Ruf? Zur Theologie des Bittgebets, München 1981; R Mössinger, Zur Lehre des Christlichen Gebets, Göttingen 1986; G Greshake und G Lohfink (Hrsg.). Bittgebet - Testfall des Glaubens, Mainz 1978 en $\mathrm{J}$ du Preez, Gebed 'n teologiese besinning, Kaapstad 1980. Vir ' $n$ behandeling van Bybelse gebede kan geraadpleeg word', R E Clements, In Spirit and Truth. Insights from Biblical Prayers, Atlanta 1985 en J P Versteeg. Het gebed volgens het Nieuwe Testament, Amsterdam 1978.

3. Vgl G W Locher, "Das vornehmste Stück der Dankbarkeit." Das Gebet im Sinne der Reformation nach dem Heidelberger Katechismus, in Handbuch zum Heidelberger Katechismus, Herausgegeben von L Coenen, Neukirchen - Vluyn 1963, 176.

4. G W Locher, Handbuch zum Heidelberger Katechismus, 173.

5. Kyk H.K., Antwoord 123.

6. Vgl G W Locher, Handbuch zum Heidelberger Katechismus, 175 e.v.

7. Kyk H M Barth, a.w., 138.

8. Vgl H W Rossouw, Klaarheid en Interpretasie, Amsterdam 1963, 149.

9. H.K., Antwoord 117.

10. Joh. 14:13.

11. I Joh. 2:1.

12. Vgl. R Deichgräber, Wachsende Ringe. Die Bibel lehrt beten, Göttingen 1983, 30.

13. Vgl. R Deichgräber, a.w., 22.

14. Kyk G W Locher, Handbuch zum Heidelberger Katechismus, 176.

15. Vgl. 1 Tess. 5:17.

16. Vgl. G W Locher, Handbuch zum Heidelberger Katechismus, 183.

17. Kyk paragraaf 2.2 hierbo.

18. Vgl. J A Heyns, Dogmatiek, Pretoria 1978, 44.

19. Kyk vraag en antwoord 122.

20. Vgl. A A van Ruler, Laat heel de aard' een loflied wezen, Nijkerk 1973, 95.

21. Vgl. J L Koole, De tien geboden, Baarn 1964, 63 e.v.

22. Kyk J L Koole, a.w., 64.

23. Vgl. Van Ruler, a.w., 94.

24. Antwoord 122.

25. Vgl. Eseg. 36:20.

26. Matt. 12:28.

27. Matt. 4:17. 
28. Openb. $2: 1-22: 5$.

29. Hierdie formulering is van $\mathrm{J}$ du Preez, a.w., 34.

30. L L J Visser, Só moet julle dan bid, Kaapstad 1977, 49.

31. Vgl. J du Preez, a.w., 34.

32. Vgl HK, Antwoord 123.

33. Rom. 7:18,19,21.

34. Antwoord 124.

35. I Kor. 15:28.

36. Kyk antwoord 124.

37. A A van Ruler, a.w., 102.

38. A A van Ruler, a.w., 103.

39. Kyk HK, vraag 116.

40. Kyk WA 56, 272, 17.

41. HK, antwoord 116.

42. Kyk HK, antwoord 126.

43. Vgl. Ef. 6:18. 